\title{
Modulation of spinal cord synaptic activity by tumor necrosis factor $\alpha$ in a model of peripheral neuropathy
}

\author{
Diana Spicarova, Vladimir Nerandzic and Jiri Palecek
}

\begin{abstract}
Background: The cytokine tumor necrosis factor $\alpha(T N F \alpha)$ is an established pain modulator in both the peripheral and central nervous systems. Modulation of nociceptive synaptic transmission in the spinal cord dorsal horn (DH) is thought to be involved in the development and maintenance of several pathological pain states. Increased levels of TNF $\alpha$ and its receptors (TNFR) in dorsal root ganglion (DRG) cells and in the spinal cord DH have been shown to play an essential role in neuropathic pain processing. In the present experiments the effect of TNF $\alpha$ incubation on modulation of primary afferent synaptic activity was investigated in a model of peripheral neuropathy.
\end{abstract}

Methods: Spontaneous and miniature excitatory postsynaptic currents (sEPSC and mEPSCs) were recorded in superficial DH neurons in acute spinal cord slices prepared from animals 5 days after sciatic nerve transection and in controls.

Results: In slices after axotomy the sEPSC frequency was $2.8 \pm 0.8 \mathrm{~Hz}$, while neurons recorded from slices after TNF $\alpha$ incubation had significantly higher sEPSC frequency $(7.9 \pm 2.2 \mathrm{~Hz})$. The effect of TNF $\alpha$ treatment was smaller in the slices from the control animals, where sEPSC frequency was $1.2 \pm 0.2 \mathrm{~Hz}$ in slices without and $2.0 \pm 0.5 \mathrm{~Hz}$ with TNF $\alpha$ incubation. Tetrodotoxin (TTX) application in slices from axotomized animals and after TNF $\alpha$ incubation decreased the mEPSC frequency to only $37.4 \pm 6.9 \%$ of the sEPSC frequency. This decrease was significantly higher than in the slices without the TNF $\alpha$ treatment $(64.4 \pm 6.4 \%)$. TTX application in the control slices reduced the sEPSC frequency to about $80 \%$ in both TNF $\alpha$ untreated and treated slices. Application of low concentration TRPV1 receptors endogenous agonist $\mathrm{N}$-oleoyldopamine (OLDA, $0.2 \mu \mathrm{M})$ in slices after axotomy induced a significant increase in mEPSC frequency $(175.9 \pm 17.3 \%)$, similar to the group with TNF $\alpha$ pretreatment (158.1 $\pm 19.5 \%)$.

Conclusions: Our results indicate that TNF $\alpha$ may enhance spontaneous transmitter release from primary afferent fibres in the spinal cord DH by modulation of TTX-sensitive sodium channels following sciatic nerve transection. This nerve injury also leads to enhanced sensitivity of presynaptic TRPV1 receptors to endogenous agonist. Modulation of presynaptic receptor activity on primary sensory terminals by TNF $\alpha$ may play an important role in neuropathic pain development.

Keywords: axotomy, sciatic nerve, dorsal horn, synaptic transmission, TRPV1, sodium channels

\section{Background}

It is now well established that neuroinflammation can facilitate or directly produce pain due to increased release of different cytokines which in turn recruit immune cells and activate glial cells $[1,2]$, especially under neuropathic conditions $[3,4]$. The cytokine tumor necrosis factor $\alpha$

\footnotetext{
* Correspondence: palecek@biomed.cas.cz

Department of Functional Morphology, Institute of Physiology, Academy of Sciences of the Czech Republic, Prague, Czech Republic
}

(TNF $\alpha$ ) is now recognized as a pain modulator participating in both the peripheral and central processes leading to neuropathic pain following peripheral nerve injury [5]. Several studies demonstrated increased TNF $\alpha$ levels in DRG [6-8] and spinal cord [9-11] in different models of peripheral neuropathy. The main sources of cytokines in the spinal cord DH are activated glial cells [1,10-12]. Recently, it was shown that acute application or incubation of spinal cord slices with TNF $\alpha$ modulates excitatory 
[13-16] and inhibitory $[17,18]$ synaptic transmission in the spinal cord DH. Furthermore, intrathecal application of exogenous TNF $\alpha$ induced mechanical allodynia and thermal hyperalgesia in rats and mice [13-15]. Pain hypersensitivity associated with peripheral neuropathy was attenuated by the TNF $\alpha$ antagonist etanercept $[19,20]$.

The effect of TNF $\alpha$ is mediated by two receptors, the TNFR1 (p55) and the TNFR2 (p75). Both receptors were detected in DRG and spinal cord neurons [21,22]. Upregulation of TNFR $1 / 2$ receptors in DRG neurons [23-25] and TNFR1 in the spinal cord DH $[11,26]$ was demonstrated in different models of peripheral neuropathy. Presumably, TNFR1 and TNFR2 differentially regulate nociceptive signaling. A crucial role of peripheral TNFR1 receptors activation was demonstrated in the CCI model of neuropathy [27]. In addition, using TNFR1 or TNFR2 knockout mice it was shown that development of thermal hyperalgesia after CCI depended upon the TNFR1 gene, whereas mechanical allodynia was present in both TNFR1 or TNFR2 knockout mice [28]. The importance of TNFR2 receptors in the excitation of primary sensory neurons after spinal nerve ligation (SNL) was demonstrated using proteins that selectively activate TNFR1 or TNFR2 receptors [29]. The same study indicated a decrease in mechanical and thermal withdrawal thresholds induced by intrathecal injection of a selective TNFR1 but not TNFR2 agonist in control rats, whereas coinjection of both selective agonists induced robust pain hypersensitivity [29]. By using TNFR1 and TNFR2 knockout mice it was shown that thermal hyperalgesia induced by intrathecal injection of TNF $\alpha$ could be mediated by both TNFR 1 or TNFR 2 receptors, but it was completely abolished in TNFR1/2 double knockout mice [15]. TNF $\alpha$ application evoked an increase in the spontaneous EPSC frequency in the superficial DH neurons, which was eliminated in the TNFR1 knockout mice and reduced in the TNFR2 -/- mice [15].

Voltage activated sodium channels (Nav), especially the tetrodotoxin-sensitive (TTX-S) Nav 1.3 and tetrodotoxinresistant (TTX-R) Nav 1.8 channels were implicated in neuropathic pain states [30]. It was demonstrated that following sciatic nerve axotomy, expression of Nav 1.3 channel mRNA was up-regulated, while Nav 1.8 mRNA was down-regulated in small DRG neurons [31,32]. This corresponds well to the observed four times faster recovery from inactivation of TTX-S sodium currents in axotomized than control small DRG neurons and downregulation of TTX-R currents [33]. Nav 1.3 channels are present in embryonic, but not in adult DRG neurons and are re-expressed under pathological condition [31]. In spinal nerve ligation (SNL) neuropathy, mechanical allodynia and thermal hyperalgesia were attenuated with reduction of TTX-R current in DRG neurons by specific knockdown of Nav 1.8 with antisense oligodeoxynucleotides [34]. Antisense oligodeoxynucleotides targeting Nav 1.8 also attenuated hypersensitivity in the chronic constriction injury (CCI) model [35]. In injured DRG neurons Nav 1.8 protein expression decreased [36], but there was an increase in Nav 1.8 immunoreactivity along the sciatic nerve following SNL [37]. It was proposed that Nav 1.8 channels in uninjured DRG neurons contribute to the hyperexcitability of these neurons, which may be critical for the development of neuropathic pain [37]. These studies indicate that the expression of Nav channels and their function in primary afferent neurons could be differentially regulated in injured and in uninjured neurons, suggesting that up-regulation of TTX-S Nav 1.3 channels is crucial in injured neurons whereas increases of TTX-R Nav 1.8 channels are more important in uninjured DRG neurons during neuropathy. Interestingly, TNF $\alpha$ may affect expression of both channels as peri-sciatic administration of TNF $\alpha$ up-regulated Nav 1.3 and 1.8 in DRG neurons [38].

Transient receptor potential vanilloid 1 receptors (TRPV1) are well recognized as molecular integrators of nociceptive stimuli in the periphery. Recently, the presynaptic TRPV1 receptors on the central branches of primary afferent neurons in the spinal cord were shown to have important roles in nociceptive synaptic signaling especially under pathological conditions [39-41]. Coexpression of TNFR1 and TRPV1 receptor mRNA [42] and colocalization of TNFR1 and TRPV1 immunoreactivity [43] was reported in subsets of DRG neurons. TNF $\alpha$ enhanced the sensitivity of cultured DRG neurons to capsaicin application [44] and induced increased expression of TRPV1 receptors on DRG [43] and trigeminal ganglion neurons [45]. This increased expression of TRPV1 receptors was TNFR1 dependent in naïve mice [43] in contrast to tumor-bearing mice, where up-regulation of TRPV1 receptors was dependent on TNFR2 [46]. In our previous experiments we have demonstrated increased sensitivity of presynaptic TRPV1 receptors to the endogenous vanilloid agonist $N$-oleoyldopamine (OLDA) after TNF $\alpha$ treatment in spinal cord slices from control animals [16]. The absence of DRG in our preparation indicated that this effect was due to phosphorylation of native TRPV1 receptors as opposed to their increased expression [47]. It was shown that capsaicin-evoked current was robustly potentiated via activation of PKC or p38/MAP kinase after TNF $\alpha$ application in cultured DRG neurons [46].

In the present study, we have examined the modulation of synaptic transmission by TNF $\alpha$ in the superficial spinal cord DH after sciatic nerve transection and in control animals. The effect of acute slice incubation with TNF $\alpha$ on the spontaneous and miniature EPSCs and on TRPV1 receptor activation by the endogenous agonist OLDA was investigated. 


\section{Methods}

All experiments were approved by the local Institutional Animal Care and Use Committee and were consistent with the guidelines of the International Association for the Study of Pain, the National Institutes of Health Guide for the Care and Use of Laboratory Animals and the European Communities Council Directive of 24 November 1986 (86/ 609/EEC).

\section{Sciatic nerve transection}

Male Wistar rats on postnatal day P18 to P22 were anesthetized with ether. For axotomy both sciatic nerves were exposed at midthigh level and transected using sharp scissors. The wound was closed and animals were left to recover in their home cages.

\section{Spinal cord slices preparation}

Acute spinal cord slices were prepared from male Wistar rats P20 - P27, as was previously described [39]. After anesthesia with ketamine (150 mg/kg, i.p.) and xylazine (16 mg/kg, i.p.), the lumbar spinal cord was removed and immersed in oxygenated ice-cold dissection solution containing (in mM): $95 \mathrm{NaCl}, 1.8 \mathrm{KCl}, 7 \mathrm{MgSO}_{4}, 0.5 \mathrm{CaCl}_{2}, 1.2$ $\mathrm{KH}_{2} \mathrm{PO}_{4}, 26 \mathrm{NaHCO}_{3}, 25 \mathrm{D}$-glucose, 50 sucrose. The spinal cord was fixed to a vibratome stage (Leica, VT $1000 \mathrm{~S}$, Germany) in a groove between two agar blocks using cyanoacrylate glue. Acute transverse slices $300 \mu \mathrm{m}$ thick were cut from lumbar segments $\mathrm{L}_{3}-\mathrm{L}_{5}$, incubated in the dissection solution for $30 \mathrm{~min}$ at $33^{\circ} \mathrm{C}$ and then stored in a recording solution at room temperature and allowed to recover for $1 \mathrm{~h}$ before the electrophysiological experiments. Recording solution contained (in $\mathrm{mM}$ ): $127 \mathrm{NaCl}, 1.8 \mathrm{KCl}$, $1.2 \mathrm{KH}_{2} \mathrm{PO}_{4}, 2.4 \mathrm{CaCl}_{2}, 1.3 \mathrm{MgSO}_{4}, 26 \mathrm{NaHCO}_{3}, 25 \mathrm{D}$-glucose. In some experiments the slices were incubated for at least $2 \mathrm{~h}$ with TNF $\alpha$ (60 nM added in the bath). Electrophysiological measurements were made from slices transferred into a recording chamber that was perfused continuously with recording solution at a rate $\sim 2 \mathrm{ml} / \mathrm{min}$. All extracellular solutions were saturated with carbogen $\left(95 \% \mathrm{O}_{2}, 5 \% \mathrm{CO}_{2}\right)$ during the whole process.

\section{Electrophysiological recordings}

Patch-clamp recordings were made from individual DH neurons visualized using a differential interference contrast (DIC) microscope (Leica, DM LFSA, Germany) equipped with an infrared-sensitive camera (IR camera Hitachi KP-200 P, Japan) with a standard TV/video monitor (Hitachi VM-172, Japan). Patch pipettes were pulled from borosilicate glass tubing (Rückl Glass, Otvovice, Czech Republic) with resistances of 3.5 - 6.0 M $\mathrm{M}$ when filled with intracellular solution. The intracellular pipette solution contained (in $\mathrm{mM}$ ): 125 gluconic acid lactone, $15 \mathrm{CsCl}, 10 \mathrm{EGTA}, 10 \mathrm{HEPES}, 1 \mathrm{CaCl}_{2}$,
$2 \mathrm{Na}_{2} \mathrm{ATP}, 0.5 \mathrm{NaGTP}$ and was adjusted to $\mathrm{pH} 7.2$ with $\mathrm{CsOH}$. Voltage-clamp recordings in the whole-cell configuration were performed with an Axopatch $200 \mathrm{~B}$ amplifier and 1440 A digitizer (Molecular Devices, USA) at room temperature $\left(\sim 23^{\circ} \mathrm{C}\right)$. Whole-cell responses were low-pass filtered at $2 \mathrm{kHz}$ and digitally sampled at $10 \mathrm{kHz}$. The series resistance of neurons was routinely compensated by $80 \%$ and was monitored during the whole experiment. AMPA receptor-mediated spontaneous or miniature EPSCs were recorded from superficial DH neurons in laminae I and II, clamped at $-70 \mathrm{mV}$ in the presence of $10 \mu \mathrm{M}$ bicuculline and $5 \mu \mathrm{M}$ strychnine. Miniature EPSCs were distinguished by addition of $0.5 \mu \mathrm{M}$ tetrodotoxin (TTX) to the recording solution. Lidocaine $(1 \mathrm{mM})$ was added in other experiments to block TTX-R sodium channels. The software package pCLAMP version 10 (Molecular Devices, USA) was used for data acquisition and subsequent off-line analysis. Neurons with capsaicin-sensitive primary afferent input were identified by an increase of EPSC frequency (> 20\%) following capsaicin $(0.2 \mu \mathrm{M})$ administration at the end of the experimental protocol.

\section{Drug treatment}

All drugs used in this study were of analytical grade and purchased from Sigma-Aldrich (Prague, Czech Republic) or Tocris Bioscience (Bristol, UK). TNF $\alpha$ was dissolved in $0.1 \%$ BSA; capsaicin and OLDA were dissolved in dimethylsulfoxide (DMSO), which had a concentration < $0.1 \%$ in the final solution.

\section{Data analysis}

Data segments of 2 min duration were analyzed for each experimental condition. Only EPSCs with an amplitude of $5 \mathrm{pA}$ or greater (which corresponded to at least twice the recording noise level) were included in the frequency analysis. In the case of amplitude analysis, the same events and data segments were used. Data are expressed as means \pm standard error of the mean (SEM). Some data were normalized as a percentage of the control values (100\%). Paired t-test, one-way ANOVA or one-way ANOVA repeated measures followed by post hoc test (Bonferroni) were used for statistical comparisons and $\mathrm{P}<$ 0.05 was considered to be statistically significant.

\section{Results}

Five days after the sciatic nerve transection spontaneous and miniature AMPA EPSCs were recorded in spinal cord slices without and after incubation with TNFa (60 nM). The absolute sEPSC frequency in the DH neurons after axotomy was $2.83 \pm 0.83 \mathrm{~Hz}$ and decreased to $1.52 \pm 0.34$ $\mathrm{Hz}(\mathrm{n}=18, \mathrm{P}<0.001)$ after TTX application (Figure 1A, C). In slices from control animals TTX application 


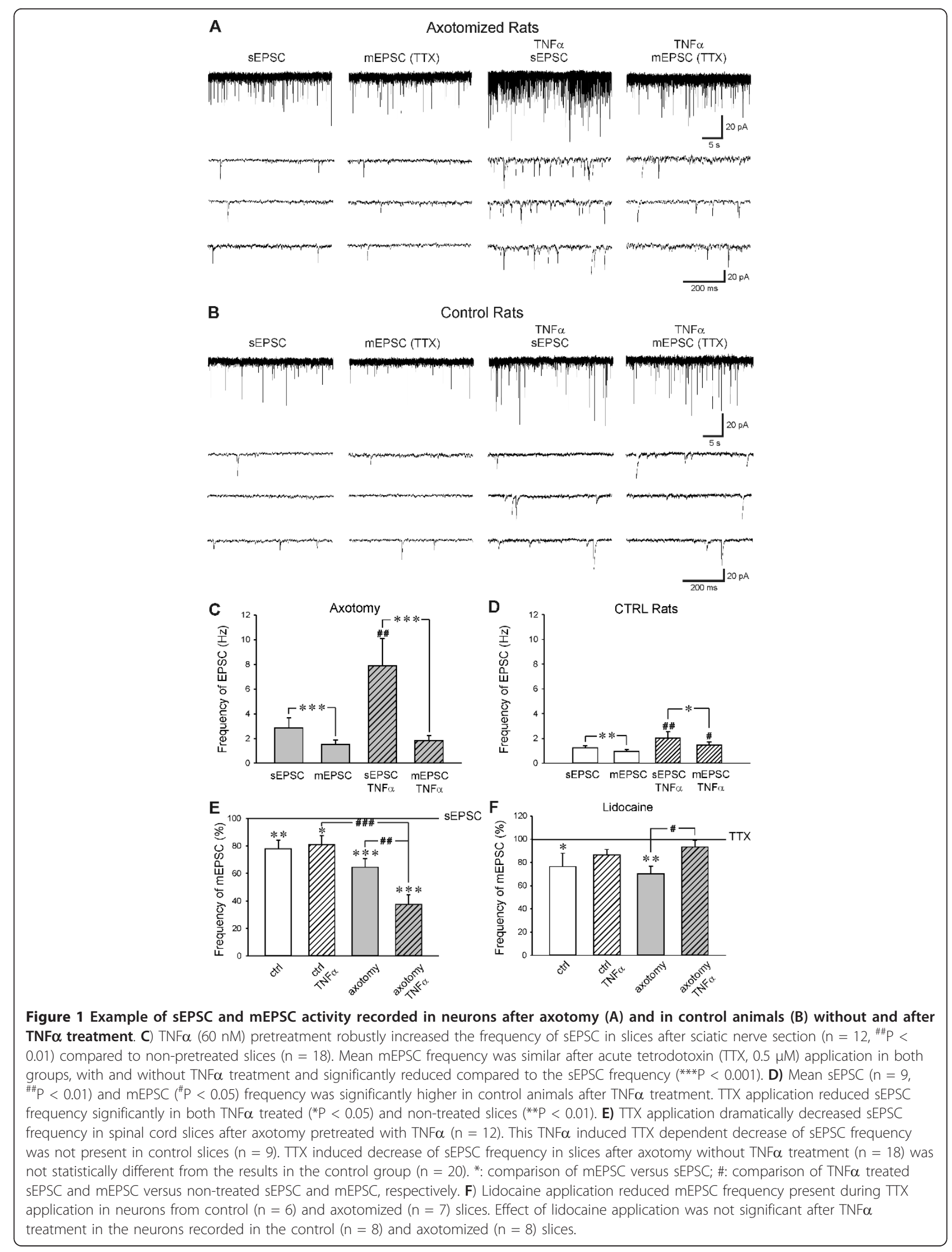


reduced sEPSC frequency from $1.23 \pm 0.20 \mathrm{~Hz}$ to $0.94 \pm$ $0.17 \mathrm{~Hz}(\mathrm{n}=20, \mathrm{P}<0.01$, Figure $1 \mathrm{~B}, \mathrm{D})$. Spontaneous and mEPSC frequency in DH neurons in slices after axotomy was higher than in control animals, but this difference was not statistically significant. In slices after axotomy incubated with TNF $\alpha$, the absolute sEPSC frequency was 7.89 $\pm 2.21 \mathrm{~Hz}$ and decreased to $1.83 \pm 0.40 \mathrm{~Hz}(\mathrm{n}=12, \mathrm{P}<$ 0.001) after TTX application (Figure 1A, C). Spontaneous EPSC frequency in TNF $\alpha$ incubated slices in control animals decreased due to TTX application from $2.03 \pm 0.53$ $\mathrm{Hz}$ to $1.45 \pm 0.25 \mathrm{~Hz}(\mathrm{n}=9, \mathrm{P}<0.05$, Figure $1 \mathrm{~B}, \mathrm{D})$. There was evident TNF $\alpha$ mediated increase of the sEPSC frequency in slices after sciatic nerve transection when compared to control slices $(\mathrm{P}<0.05)$, while the low difference between mEPSC in these two groups was not significant (Figure 1C, D). These results indicate that TNF $\alpha$ increases sEPSC frequency in axotomized DH neurons via enhanced activity at TTX-S Nav channels. This is even more evident after standardization of the results. Under this evaluation, tetrodotoxin application reduced the frequency of spontaneous EPSC to $64.4 \pm 6.4 \%(\mathrm{n}=18, \mathrm{P}<$ 0.001 ) in neurons after axotomy without TNF $\alpha$ treatment, but these were decreased to only $37.4 \pm 6.9 \%(\mathrm{n}=12, \mathrm{P}<$ 0.001 ) with TTX application in spinal cord slices pretreated with TNFa (Figure 1E). This robust TTX induced decrease of EPSC frequency in TNF $\alpha$ pretreated slices was statistically different from the TTX effect in non-pretreated slices in the axotomy group $(\mathrm{P}<0.01)$ and from the TTX effect in control animals $(\mathrm{P}<0.001)$. There was no difference between the TTX induced reductions of EPSC frequency in neurons incubated with TNF $\alpha(80.9 \pm$ 6.6, $\mathrm{n}=9, \mathrm{P}<0.05)$ and non-pretreated slices $(77.8 \pm 6.4$, $\mathrm{n}=20, \mathrm{P}<0.01)$ in control animals.

The mean amplitude of the sEPSC was $29.7 \pm 2.5 \mathrm{pA}$ in the neurons after axotomy and decreased to $25.2 \pm 2.0$ pA (mEPSC) after TTX application $(\mathrm{n}=18, \mathrm{P}<0.001$, Figure $2 \mathrm{~A}$ ). In the group of TNF $\alpha$ pretreated neurons after axotomy the results were similar, with mean sEPSC amplitude of $35.2 \pm 4.7 \mathrm{pA}$ and mEPSC amplitude $28.6 \pm$ $3.0 \mathrm{pA}(\mathrm{n}=12, \mathrm{P}<0.01)$. In control animals, the mean sEPSC amplitude $(29.7 \pm 2.2 \mathrm{pA})$ decreased after TTX application to $25.9 \pm 1.4 \mathrm{pA}(\mathrm{n}=20, \mathrm{P}<0.05)$. Control TNF $\alpha$ pretreated neurons had sEPSC amplitude of $22.6 \pm$ $1.9 \mathrm{pA}$ and mEPSC of $21.1 \pm 1.8 \mathrm{pA}(\mathrm{n}=9)$. Neither sEPSC or mEPSC amplitudes were statistically different between the DH neurons in TNF $\alpha$ pretreated slices and non-treated slices from both injured and control animals. The standardized mean sEPSC amplitudes (100\%) were higher than the mEPSC amplitudes in both axotomized and control slices, with and without TNF $\alpha$ treatment (Figure 2B). There was no difference in the TTX induced reduction of the mean $\mathrm{SEPSC}$ amplitude between the TNF $\alpha$ treated $(85.1 \pm 4.2 \%, \mathrm{n}=12, \mathrm{P}<0.01)$ and nontreated group $(86.2 \pm 2.6 \%, \mathrm{n}=18, \mathrm{P}<0.001)$ after axotomy (Figure $2 \mathrm{~B}$ ). In slices from the control rats, the TTX induced reduction of the mean sEPSC amplitude was only small, $94.7 \pm 4.2 \%(\mathrm{n}=9)$ in the TNF $\alpha$ pretreated group and $91.1 \pm 3.3 \%(\mathrm{n}=20, \mathrm{P}<0.05)$ in the slices without $\mathrm{TNF} \alpha$ treatment.

To assess the role of TTX-R Nav channels, lidocaine (1 $\mathrm{mM}$ ) was used together with TTX in some experiments. In slices from axotomized animals the mEPSC frequency decreased after lidocaine application to $70.1 \pm 6.6 \%$ ( $n=$ $7, \mathrm{P}<0.01$ ), when mEPSC frequency during the TTX application was considered $100 \%$ (Figure 1F). In axotomized slices with TNF $\alpha$ treatment, lidocaine application did not induce significant change in $\mathrm{mEPSC}$ frequency $(93.3 \pm 6.0 \%, \mathrm{n}=8)$ from the TTX level, but was significantly different from the TNF $\alpha$ untreated slices $(\mathrm{P}<$ 0.05). In DH neurons from control animals the mEPSC frequency decreased after lidocaine application to $76.5 \pm$ $11.4 \%(\mathrm{n}=6, \mathrm{P}<0.05)$. The decrease of mEPSC frequency after lidocaine application in TNF $\alpha$ treated control slices $(86.3 \pm 4.9 \%, \mathrm{n}=8)$ was not statistically different from the frequency during the TTX application or from recordings in the control slices without TNF $\alpha$ treatment.

The mean amplitude of the mEPSCs recorded in the presence of lidocaine was not different from mEPSC amplitude recorded in the presence of TTX only (axotomy: $104.8 \pm 3.5 \%$, axotomy with TNF $\alpha$ : $103.1 \pm 7.3 \%$, CTRL: $97.7 \pm 2.9 \%$, CTRL with TNFo: $91.3 \pm 3.3 \%$ ).

Next, TNFa modulation of spinal TRPV1 receptors activation by endogenous agonist OLDA after sciatic nerve transection was investigated. We have previously demonstrated that application of a low concentration OLDA $(0.2 \mu \mathrm{M})$ does not evoke any changes in the mEPSC frequency in control slices $[16,39]$. This was also confirmed in the present experiments, where application of $0.2 \mu \mathrm{M}$ OLDA solution did not change the mEPSC frequency $(94.8 \pm 5.0 \%, \mathrm{n}=6)$ in slices from control animals. However, the application of low concentration OLDA solution $(0.2 \mu \mathrm{M})$ increased the mEPSC frequency to $175.9 \pm 17.3 \%$ $(\mathrm{n}=13, \mathrm{P}<0.01)$ when compared to the control values before the OLDA application, in acute spinal cord slices prepared from animals 5 days after the sciatic nerve transection (Figure 3A). Final capsaicin application $(0.2 \mu \mathrm{M})$ increased the mEPSC frequency substantially $(699.2 \pm$ $426.9 \%$ ), in this group of DH neurons. OLDA application in the neurons recorded in slices after axotomy and with the TNF $\alpha$ pretreatment increased the MEPSC frequency $158.1 \pm 19.5 \%(\mathrm{n}=14, \mathrm{P}<0.05)$ and the capsaicin application increased mEPSC frequency to $860.2 \pm 343.2 \%$. OLDA induced increase of the mEPSC frequency was not statistically different between the TNF $\alpha$ pretreated and non-treated slices from the axotomized animals. The mEPSC frequency (in $\mathrm{Hz}$ ) recorded in the TNFa incubated slices prepared from the animals after axotomy was 


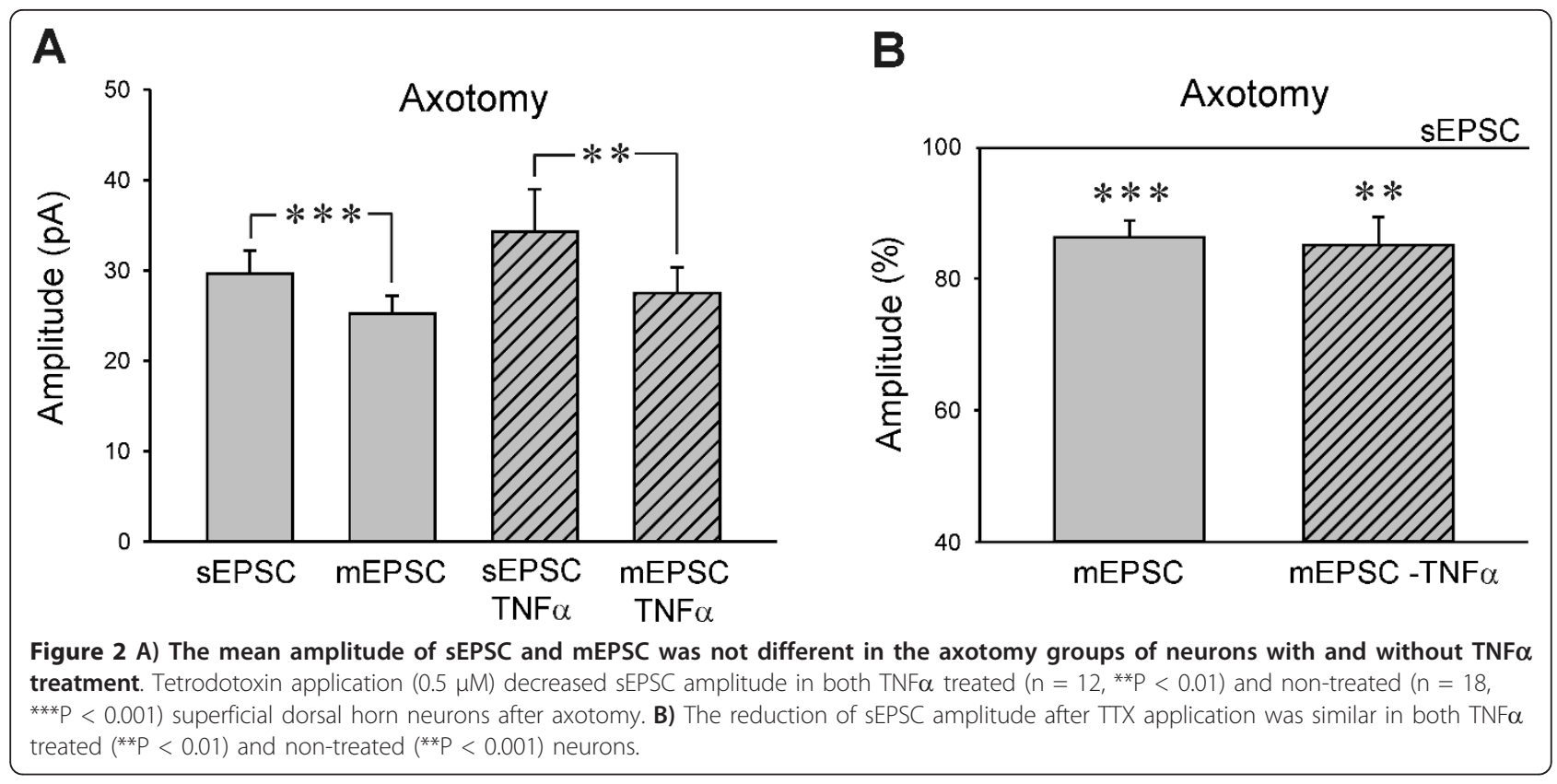

higher (mEPSC: $2.17 \pm 0.63 \mathrm{~Hz}$, OLDA: $2.76 \pm 0.75 \mathrm{~Hz}, \mathrm{n}$ $=14$ ) when compared to the mEPSC frequency recorded in slices without TNF $\alpha$ treatment (mEPSC: $0.97 \pm 0.22$ $\mathrm{Hz}$, OLDA: $1.51 \pm 0.30 \mathrm{~Hz}, \mathrm{n}=13$, Figure 3B), but this difference was not statistically significant. All of the tested neurons responded to capsaicin application. OLDA application did not change the mean mEPSC amplitude in the recorded superficial DH neurons without (mEPSC: $23.7 \pm$ $2.5 \mathrm{pA}$, OLDA: $23.6 \pm 2.6 \mathrm{pA}, \mathrm{n}=13$ ) and with TNF $\alpha$ pretreatment (mEPSC: $28.0 \pm 2.9 \mathrm{pA}$, OLDA: $25.9 \pm 2.7 \mathrm{pA}, \mathrm{n}$
=14) following peripheral nerve injury, similar to our results demonstrated in control animals [39].

\section{Discussion}

There is now mounting evidence of TNF $\alpha$ importance in the processing of nociceptive information at the spinal cord level following peripheral nerve injury. In our study we have examined the possible role of TNF $\alpha$ in modulation of synaptic transmission at superficial DH neurons in a model of peripheral neuropathy. Our
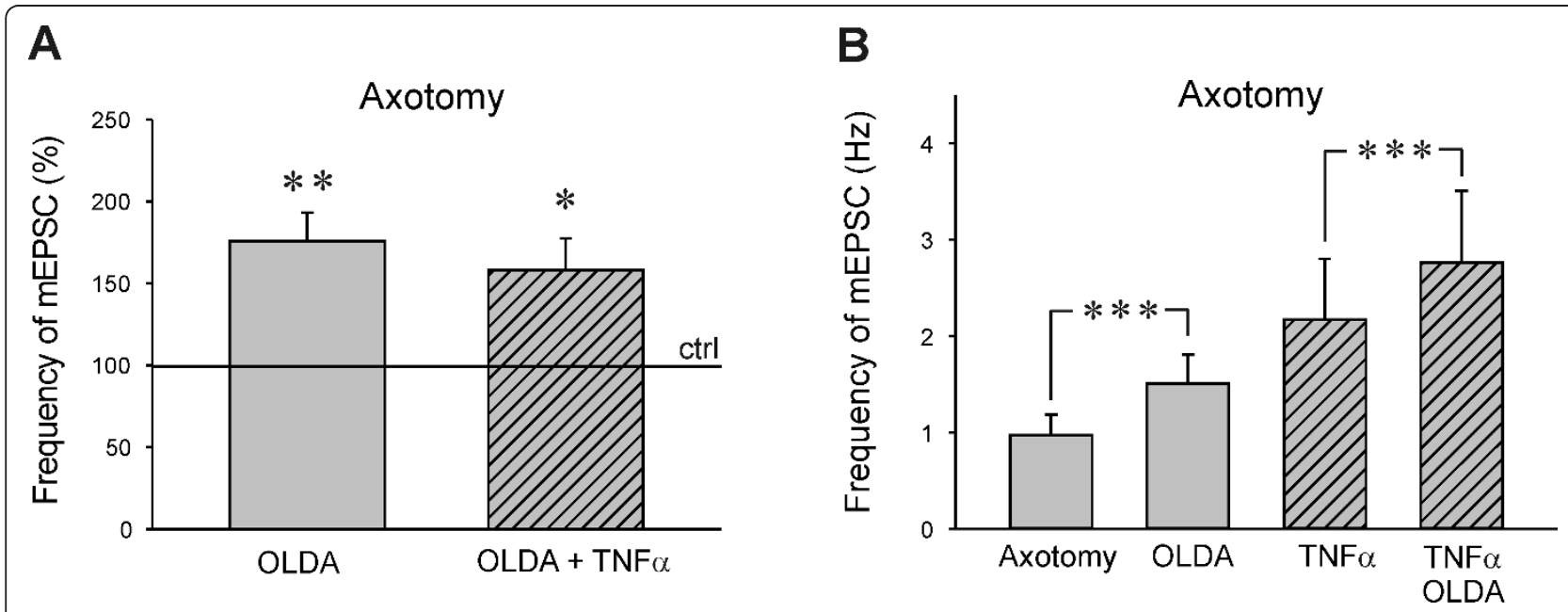

Figure $3 \mathrm{~A}$ ) Neurons recorded in slices after axotomy showed increased mEPSC frequency after endogenous TRPV1 agonist $N$ oleoyldopamine application (OLDA, $0.2 \mu \mathrm{M}, \mathbf{n}=\mathbf{1 3}$, **P $<.01$ ). The OLDA induced mEPSC frequency increase was similar in TNF $\alpha$ treated slices $\left(n=14,{ }^{*} P<<0.05\right)$. B) The absolute mEPSC frequency recorded in the neurons after TNF $\alpha$ treatment was higher compared to the nontreated group, but this difference did not reach statistical significance. 
results showed increased TNFa mediated regulation of presynaptic TTX-S sodium channels activity, 5 days after sciatic nerve axotomy. The nerve injury also increased sensitivity of presynaptic TRPV1 receptors to endogenous agonist OLDA. These changes in function of presynaptic primary afferent ending in our experiments were most likely related to nociception in vivo, as the neurons recorded were in the superficial DH laminae and most of them received capsaicin sensitive input.

TNF $\alpha$ in our experiments induced robust increases of sEPSC frequency in the DH neurons recorded after the sciatic nerve transection, while in control animals the effect of TNF $\alpha$ incubation was only moderate. This TNF $\alpha$ induced sEPSC frequency increase after nerve injury was most likely mediated by increased expression of TNFR1 receptors and activation of TTX-S Nav channels, as TTX application reduced the sEPSC frequency to only $37 \%$ of the original level. The cytokines were shown to have significant impact on sodium channels activity in vitro and in different models of neuropathic pain. In cultured DRG neurons TNF $\alpha$ enhanced TTX-R sodium currents via activation of TNFR1 receptors and p38 MAPK [48]. Model of neuropathy induced by L5 ventral root transection (L5-VRT) accompanied with mechanical allodynia and thermal hyperalgesia increased immunoreactivity for TNF $\alpha$ and TNFR1 receptors in the ipsilateral DRG and bilaterally in the spinal cord DH [26]. Inhibition of TNF $\alpha$ synthesis in this model, prevented p38 MAPK activation in DRG neurons and spinal cord microglia, which was necessary for the initiation and maintenance of neuropathic pain [49]. The L5VRT also increased Nav 1.3 and Nav 1.8 mRNA, protein level and current densities of TTX-S and TTX-R sodium channels in DRG neurons [38]. Interestingly, both Nav 1.3 and Nav 1.8 up-regulation was mediated by cytokine TNF $\alpha$, as was shown by inhibition of TNF $\alpha$ synthesis $[26,38]$. The increase of sodium currents in DRG neurons evoked by L5-VRT was not present in TNRF1 knockout mice [50]. Our results in the peripheral nerve axotomy model suggest increased glutamate release from the presynaptic primary afferent endings in the spinal cord due to TTX-S Nav channels activity. The DRG cell bodies were absent during the incubation of spinal cord slices with TNF $\alpha$. Therefore the increased spontaneous activity was most likely mediated through modulation of TTX-S Nav channels function, such as their phosphorylation/dephosphorylation [51], trafficking from the cytoplasm to the presynaptic membrane [52] or possibly also by their local synthesis in the presynaptic ending. Recently ERK1/2 mitogen-activated protein kinase phosphorylation of TTX-S Nav 1.7 channels was shown to regulate gating properties of the channel and resting membrane properties of DRG neurons [53]. The Nav 1.3 channels up-regulated following axotomy display rapid activation and inactivation [31,33]. It was suggested that the increased recovery rates from inactivation of Nav 1.3 channels expressed along the axon after axotomy compared to Nav 1.7 channels present under control conditions in small DRG neurons, could contribute to increased excitability of DRG neurons under neuropathic pain conditions [30]. Presynaptic Nav channels modulate the presynaptic action potential, subsequent $\mathrm{Ca}^{2+}$ influx and thus transmitter release. Increased expression of TTX-S channels at the presynaptic ending could thus lead to amplification of the presynaptic potential and increased $\mathrm{Ca}^{2+}$ influx and glutamate release [54]. Our results support the hypothesis that presynaptic TTX-S Nav channels on spinal cord primary afferent endings could mediate increased transmitter release and thus contribute to neuropathic pain hypersensitivity.

Our results with lidocaine application showed involvement of presynaptic TTX-R Nav channels in regulation of mEPSC frequency recorded in superficial dorsal horn neurons. There was no significant difference between the control and axotomized animals. Minimal effect of lidocaine application on the mEPSC frequency in neurons from axotomized slices after TNF $\alpha$ incubation suggested reduced participation of TTX-R Nav channels under these conditions. Downregulation of Nav 1.8 channel mRNA expression [32] and TTX-R sodium currents [33] has been shown in DRG neurons following sciatic nerve axotomy. In our preparation TTX-R Nav channel involvement in regulation of mEPSCs frequency was significantly reduced after the TNF $\alpha$ treatment, suggesting important regulatory role of this cytokine. In contrast, Jin and Gereau (2006) demonstrated enhancement of TTX$\mathrm{R}$ sodium currents in cultured DRG neurons after acute TNF $\alpha$ application. This discrepancy is most likely due to different experimental conditions between the DRG cultures and the spinal cord slices with only central branch of the primary afferent present, different duration of the TNF $\alpha$ application and altered regulation of TTX-R Nav channels in injured and uninjured DRG neurons by TNF $\alpha[38,50]$.

In our experiments there was only a small reduction of the mean sEPSC amplitude after TTX application, irrespective of the TNF $\alpha$ treatment (control slices 93\%, axotomy $\sim 86 \%$ ). This would suggest that there was very low proportion of sEPSC present due to propagation of action potentials in the superficial DH neurons in our spinal slice preparation with cut dorsal roots before the TTX treatment, in contrast to preparations with intact neuronal circuits as in hippocampal slice preparation [55]. The TNF $\alpha$ treatment did not induce any significant change in sEPSC or mEPSC mean amplitude in the recorded neurons, similar to our previous results in control animals [16] and in agreement with previous finding 
$[13,15,56]$. However, enhancement of AMPA mediated postsynaptic currents by TNF $\alpha$ was shown in hippocampal neurons due to increased expression of surface AMPA receptor [57]. In the spinal cord, TNF $\alpha$ dependent AMPA receptor trafficking was demonstrated in association with peripheral inflammation [58] and cell death following spinal cord injury [59]. Potentiation of AMPA induced currents by TNF $\alpha$ was reported also in the spinal cord DH neurons in control slices [13], while two other studies did not find any TNF $\alpha$ modulation of AMPA induced currents in DH neurons [15,56].

Our previous experiments on superficial DH neurons done under the same experimental conditions showed that application of $10 \mu \mathrm{M}$ OLDA solution was needed to increase mEPSC frequency due to specific TRPV1 receptor activation, while lower OLDA concentrations did not have an effect [39]. The OLDA concentration needed to activate presynaptic TRPV1 receptors decreased dramatically to $0.2 \mu \mathrm{M}$ after PKC activation by phorbol esters and in a model of peripheral inflammation [39]. Results in this paper demonstrate increased sensitivity of spinal presynaptic TRPV1 receptors to endogenous agonist OLDA following sciatic nerve transection. We suggest that this responsiveness to low concentration $(0.2 \mu \mathrm{M})$ OLDA solution could be mediated by phosphorylation or up-regulation of presynaptic TRPV1 receptors [60]. One of the mechanisms involved could be also increased expression of TNFR1 receptors in the DRG neurons following the nerve lesion [11]. In the experiments described in this paper, the increase of mEPSC frequency after the OLDA application was comparable in the neurons recorded after axotomy irrespective of the TNF $\alpha$ treatment. This is in contrast to our previous results in control slices, where TNF $\alpha$ treatment induced response to low concentration $(0.2 \mu \mathrm{M})$ OLDA, not present in controls [16]. The lack of TNFa incubation effect in slices after axotomy may be due to already sensitized TRPV1 receptors present at the presynaptic endings. Decreased expression of TRPV1 receptors after axotomy could also play a role [61].

\section{Conclusions}

Our results support an important regulatory role of the proinflammatory cytokine TNF $\alpha$ in nociceptive processing at the spinal cord DH following sciatic nerve section. We have demonstrated modulation of presynaptic TTX sensitive sodium channel activity and increased transmitter release by TNF $\alpha$ together with increased sensitivity of presynaptic TRPV1 receptors to endogenous agonist. These mechanisms could significantly affect synaptic transmission in the spinal cord DH after nerve injury and contribute to neuropathic pain development or maintenance.

\section{Acknowledgements}

This work was supported by GACR 305/09/1228, MSMT LC554, GAUK 309211 , P303/12/P510, AV0Z 50110509.

\section{Authors' contributions}

JP conceived and designed the study, DS and VN performed and analyzed the experiments. DS and JP drafted the manuscript. All authors have read and approved the final version of the manuscript.

\section{Competing interests}

The authors declare that they have no competing interests.

Received: 27 September 2011 Accepted: 21 December 2011 Published: 21 December 2011

\section{References}

1. McMahon SB, Cafferty WB, Marchand F: Immune and glial cell factors as pain mediators and modulators. Exp Neurol 2005, 192:444-462.

2. Marchand F, Perretti M, McMahon SB: Role of the immune system in chronic pain. Nat Rev Neurosci 2005, 6:521-532.

3. Scholz J, Woolf CJ: The neuropathic pain triad: neurons, immune cells and glia. Nat Neurosci 2007, 10:1361-1368.

4. Sommer C: Painful neuropathies. Curr Opin Neurol 2003, 16:623-628.

5. Leung L, Cahill CM: TNF-alpha and neuropathic pain-a review. J Neuroinflammation 2010, 7:27.

6. Jancalek R, Dubovy P, Svizenska I, Klusakova I: Bilateral changes of TNFalpha and IL-10 protein in the lumbar and cervical dorsal root ganglia following a unilateral chronic constriction injury of the sciatic nerve. J Neuroinflammation 2010, 7:11.

7. Schafers M, Geis C, Brors D, Yaksh TL, Sommer C: Anterograde transport of tumor necrosis factor-alpha in the intact and injured rat sciatic nerve. $J$ Neurosci 2002, 22:536-545.

8. Schafers M, Geis C, Svensson Cl, Luo ZD, Sommer C: Selective increase of tumour necrosis factor-alpha in injured and spared myelinated primary afferents after chronic constrictive injury of rat sciatic nerve. Eur J Neurosci 2003, 17:791-804.

9. DeLeo JA, Colburn RW, Rickman AJ: Cytokine and growth factor immunohistochemical spinal profiles in two animal models of mononeuropathy. Brain Res 1997, 759:50-57.

10. Winkelstein BA, Rutkowski MD, Sweitzer $S M$, Pahl JL, DeLeo JA: Nerve injury proximal or distal to the DRG induces similar spinal glial activation and selective cytokine expression but differential behavioral responses to pharmacologic treatment. J Comp Neurol 2001, 439:127-139.

11. Ohtori S, Takahashi K, Moriya H, Myers RR: TNF-alpha and TNF-alpha receptor type 1 upregulation in glia and neurons after peripheral nerve injury: studies in murine DRG and spinal cord. Spine (Phila Pa 1976) 2004, 29:1082-1088.

12. Hao S, Mata M, Glorioso JC, Fink DJ: Gene transfer to interfere with TNFalpha signaling in neuropathic pain. Gene Ther 2007, 14:1010-1016.

13. Kawasaki Y, Zhang L, Cheng JK, Ji RR: Cytokine mechanisms of central sensitization: distinct and overlapping role of interleukin-1 beta, interleukin-6, and tumor necrosis factor-alpha in regulating synaptic and neuronal activity in the superficial spinal cord. J Neurosci 2008, 28:5189-5194.

14. Gao YJ, Zhang L, Samad OA, Suter MR, Yasuhiko K, Xu ZZ, Park JY, Lind AL, $\mathrm{Ma} Q$, Ji RR: JNK-induced MCP-1 production in spinal cord astrocytes contributes to central sensitization and neuropathic pain. J Neurosci 2009, 29:4096-4108.

15. Zhang L, Berta T, Xu ZZ, Liu T, Park JY, Ji RR: TNF-alpha contributes to spinal cord synaptic plasticity and inflammatory pain: distinct role of TNF receptor subtypes 1 and 2. Pain 2011, 152:419-427.

16. Spicarova D, Palecek J: Tumor necrosis factor alpha sensitizes spinal cord TRPV1 receptors to the endogenous agonist N-oleoyldopamine. J Neuroinflammation 2010, 7:49.

17. Zhang $H$, Nei $H$, Dougherty PM: A p38 mitogen-activated protein kinasedependent mechanism of disinhibition in spinal synaptic transmission induced by tumor necrosis factor-alpha. J Neurosci 2010, 30:12844-12855.

18. Zhang H, Dougherty PM: Acute inhibition of signalling phenotype of spinal GABAergic neurons by tumour necrosis factor. J Physiol 2011, 589:4511-4526. 
19. Schafers M, Svensson Cl, Sommer C, Sorkin LS: Tumor necrosis factor-alpha induces mechanical allodynia after spinal nerve ligation by activation of p38 MAPK in primary sensory neurons. J Neurosci 2003, 23:2517-2521.

20. Sommer C, Schafers M, Marziniak M, Toyka KV: Etanercept reduces hyperalgesia in experimental painful neuropathy. J Peripher Nerv Syst 2001, 6:67-72.

21. Pollock J, McFarlane SM, Connell MC, Zehavi U, Vandenabeele P, MacEwan DJ, Scott RH: TNF-alpha receptors simultaneously activate Ca2+ mobilisation and stress kinases in cultured sensory neurones. Neuropharmacology 2002, 42:93-106.

22. Yan P, Liu N, Kim GM, Xu J, Xu J, Li Q, Hsu CY, Xu XM: Expression of the type 1 and type 2 receptors for tumor necrosis factor after traumatic spinal cord injury in adult rats. Exp Neurol 2003, 183:286-297.

23. Dubovy P, Jancalek R, Klusakova I, Svizenska I, Pejchalova K: Intra- and extraneuronal changes of immunofluorescence staining for TNF-alpha and TNFR1 in the dorsal root ganglia of rat peripheral neuropathic pain models. Cell Mol Neurobiol 2006, 26:1205-1217.

24. Shubayev VI, Myers RR: Axonal transport of TNF-alpha in painful neuropathy: distribution of ligand tracer and TNF receptors. $J$ Neuroimmunol 2001, 114:48-56.

25. Schafers M, Sorkin LS, Geis C, Shubayev VI: Spinal nerve ligation induces transient upregulation of tumor necrosis factor receptors 1 and 2 in injured and adjacent uninjured dorsal root ganglia in the rat. Neurosci Lett 2003, 347:179-182.

26. $X u$ JT, Xin WJ, Zang Y, Wu CY, Liu XG: The role of tumor necrosis factoralpha in the neuropathic pain induced by Lumbar 5 ventral root transection in rat. Pain 2006, 123:306-321.

27. Sommer C, Schmidt C, George A: Hyperalgesia in experimental neuropathy is dependent on the TNF receptor 1. Exp Neurol 1998, 151:138-142.

28. Vogel C, Stallforth S, Sommer C: Altered pain behavior and regeneration after nerve injury in TNF receptor deficient mice. J Peripher Nerv Syst 2006, 11:294-303.

29. Schafers M, Sommer C, Geis C, Hagenacker T, Vandenabeele P, Sorkin LS: Selective stimulation of either tumor necrosis factor receptor differentially induces pain behavior in vivo and ectopic activity in sensory neurons in vitro. Neuroscience 2008, 157:414-423.

30. Cummins TR, Sheets PL, Waxman SG: The roles of sodium channels in nociception: Implications for mechanisms of pain. Pain 2007, 131:243-257.

31. Waxman SG, Kocsis JD, Black JA: Type III sodium channel mRNA is expressed in embryonic but not adult spinal sensory neurons, and is reexpressed following axotomy. J Neurophysiol 1994, 72:466-470.

32. Dib-Hajj S, Black JA, Felts P, Waxman SG: Down-regulation of transcripts for Na channel alpha-SNS in spinal sensory neurons following axotomy. Proc Natl Acad Sci USA 1996, 93:14950-14954.

33. Cummins TR, Waxman SG: Downregulation of tetrodotoxin-resistant sodium currents and upregulation of a rapidly repriming tetrodotoxinsensitive sodium current in small spinal sensory neurons after nerve injury. J Neurosci 1997, 17:3503-3514.

34. Lai J, Gold MS, Kim CS, Bian D, Ossipov MH, Hunter JC, Porreca F: Inhibition of neuropathic pain by decreased expression of the tetrodotoxinresistant sodium channel, NaV1.8. Pain 2002, 95:143-152.

35. Joshi SK, Mikusa JP, Hernandez G, Baker S, Shieh CC, Neelands T, Zhang XF, Niforatos W, Kage K, Han P, Krafte D, Faltynek C, Sullivan JP, Jarvis MF, Honore P: Involvement of the TX-resistant sodium channel Nav 1.8 in inflammatory and neuropathic, but not post-operative, pain states. Pain 2006, 123:75-82.

36. Decosterd I, Ji RR, Abdi S, Tate S, Woolf CJ: The pattern of expression of the voltage-gated sodium channels $\mathrm{Na}(\mathrm{v}) 1.8$ and $\mathrm{Na}(\mathrm{v}) 1.9$ does not change in uninjured primary sensory neurons in experimental neuropathic pain models. Pain 2002, 96:269-277.

37. Gold MS, Weinreich D, Kim CS, Wang R, Treanor J, Porreca F, Lai J: Redistribution of $\mathrm{Na}(\mathrm{V}) 1.8$ in uninjured axons enables neuropathic pain. J Neurosci 2003, 23:158-166.

38. He XH, Zang $Y$, Chen $X$, Pang RP, Xu JT, Zhou X, Wei XH, Li YY, Xin WJ, Qin ZH, Liu XG: TNF-alpha contributes to up-regulation of Nav1.3 and Nav1.8 in DRG neurons following motor fiber injury. Pain 2010, 151:266-279.

39. Spicarova D, Palecek J: The role of the TRPV1 endogenous agonist NOleoyldopamine in modulation of nociceptive signaling at the spinal cord level. J Neurophysiol 2009, 102:234-243.

40. Premkumar LS: Targeting TRPV1 as an alternative approach to narcotic analgesics to treat chronic pain conditions. AAPS J 2010, 12:361-370.
41. Spicarova D, Palecek J: The role of spinal cord vanilloid (TRPV1) receptors in pain modulation. Physiol Res 2008, 57(Suppl 3):S69-77.

42. Li Y, Ji A, Weihe E, Schafer MK: Cell-specific expression and lipopolysaccharide-induced regulation of tumor necrosis factor alpha (TNFalpha) and TNF receptors in rat dorsal root ganglion. J Neurosci 2004, 24:9623-9631.

43. Hensellek S, Brell P, Schaible HG, Brauer R, Segond von Banchet G: The cytokine TNFalpha increases the proportion of DRG neurones expressing the TRPV1 receptor via the TNFR1 receptor and ERK activation. Mol Cell Neurosci 2007, 36:381-391.

44. Nicol GD, Lopshire JC, Pafford CM: Tumor necrosis factor enhances the capsaicin sensitivity of rat sensory neurons. J Neurosci 1997, 17:975-982.

45. Khan AA, Diogenes A, Jeske NA, Henry MA, Akopian A, Hargreaves KM: Tumor necrosis factor alpha enhances the sensitivity of rat trigeminal neurons to capsaicin. Neuroscience 2008, 155:503-509.

46. Constantin CE, Mair N, Sailer CA, Andratsch M, Xu ZZ, Blumer MJ, Scherbakov N, Davis JB, Bluethmann H, Ji RR, Kress M: Endogenous tumor necrosis factor alpha (TNFalpha) requires TNF receptor type 2 to generate heat hyperalgesia in a mouse cancer model. J Neurosci 2008, 28:5072-5081.

47. Huang J, Zhang X, McNaughton PA: Modulation of temperature-sensitive TRP channels. Semin Cell Dev Biol 2006, 17:638-645.

48. Jin X, Gereau RWt: Acute p38-mediated modulation of tetrodotoxinresistant sodium channels in mouse sensory neurons by tumor necrosis factor-alpha. J Neurosci 2006, 26:246-255.

49. Xu JT, Xin WJ, Wei XH, Wu CY, Ge YX, Liu YL, Zang Y, Zhang T, Li YY, Liu XG: p38 activation in uninjured primary afferent neurons and in spinal microglia contributes to the development of neuropathic pain induced by selective motor fiber injury. Exp Neurol 2007, 204:355-365.

50. Chen X, Pang RP, Shen KF, Zimmermann M, Xin WJ, Li YY, Liu XG: TNFalpha enhances the currents of voltage gated sodium channels in uninjured dorsal root ganglion neurons following motor nerve injury. Exp Neurol 2011, 227:279-286.

51. Scheuer T: Regulation of sodium channel activity by phosphorylation. Semin Cell Dev Biol 2011, 22:160-165.

52. Shao D, Okuse K, Djamgoz MB: Protein-protein interactions involving voltage-gated sodium channels: Post-translational regulation, intracellular trafficking and functional expression. Int J Biochem Cell Biol 2009, 41:1471-1481.

53. Stamboulian S, Choi JS, Ahn HS, Chang YW, Tyrrell L, Black JA, Waxman SG, Dib-Hajj SD: ERK1/2 mitogen-activated protein kinase phosphorylates sodium channel $\mathrm{Na}(\mathrm{v}) 1.7$ and alters its gating properties. J Neurosci 2010, 30:1637-1647.

54. Engel D, Jonas P: Presynaptic action potential amplification by voltagegated $\mathrm{Na}+$ channels in hippocampal mossy fiber boutons. Neuron 2005, 45:405-417.

55. Hsia AY, Malenka RC, Nicoll RA: Development of excitatory circuitry in the hippocampus. J Neurophysiol 1998, 79:2013-2024.

56. Youn DH, Wang H, Jeong SJ: Exogenous tumor necrosis factor-alpha rapidly alters synaptic and sensory transmission in the adult rat spinal cord dorsal horn. J Neurosci Res 2008, 86:2867-2875.

57. Beattie EC, Stellwagen D, Morishita W, Bresnahan JC, Ha BK, Von Zastrow M, Beattie MS, Malenka RC: Control of synaptic strength by glial TNFalpha. Science 2002, 295:2282-2285.

58. Choi Jl, Svensson Cl, Koehrn FJ, Bhuskute A, Sorkin LS: Peripheral inflammation induces tumor necrosis factor dependent AMPA receptor trafficking and Akt phosphorylation in spinal cord in addition to pain behavior. Pain 2010, 149:243-253.

59. Ferguson AR, Christensen RN, Gensel JC, Miller BA, Sun F, Beattie EC, Bresnahan JC, Beattie MS: Cell death after spinal cord injury is exacerbated by rapid TNF alpha-induced trafficking of GluR2-lacking AMPARs to the plasma membrane. J Neurosci 2008, 28:11391-11400.

60. Zhang $X$, Huang J, McNaughton PA: NGF rapidly increases membrane expression of TRPV1 heat-gated ion channels. EMBO J 2005, 24:4211-4223.

61. Staaf S, Oerther S, Lucas G, Mattsson JP, Ernfors P: Differential regulation of TRP channels in a rat model of neuropathic pain. Pain 2009, 144:187-199.

doi:10.1186/1742-2094-8-177

Cite this article as: Spicarova et al:: Modulation of spinal cord synaptic activity by tumor necrosis factor $\alpha$ in a model of peripheral neuropathy. Journal of Neuroinflammation 2011 8:177. 